\section{An Evaluation of Containerized Plants for Strawberries Growing in a Subtropical Environment}

\author{
C.M. Menzel ${ }^{1}$ and A. Toldi
}

AdDITIONAL INDEX wORDs. Fragaria $\times$ ananassa, bare-rooted, economic returns, nursery material, propagation

SUMMARY. The productivity of containerized and bare-rooted plants of strawberry (Fragaria $\times$ ananassa) was investigated over 4 years in southeastern Queensland, Australia. In the first experiment, plants in small, $75-\mathrm{cm}^{3}$ cells were compared with bare-rooted plants of 'Festival' and 'Sugarbaby'. A similar experiment was conducted in year 2 with these two cultivars, plus 'Rubygem'. In year 3, plants in large, $125-\mathrm{cm}^{3}$ cells were compared with small and large bare-rooted plants of 'Festival' and 'Rubygem'. Treatments in each of these experiments were planted on the same date. In the final experiment, plants in large cells and bare-rooted plants of 'Festival' were planted in late March, early April, mid-April, or early May. The plants grown in small cells produced $60 \%$ to $85 \%$ of the yields of the bare-rooted plants, whereas the yield of plants in large cells was equal to that of the bare-rooted plants. Containerized plants are twice as expensive as bare-rooted plants (A\$0.60 vs. A \$0.32) (A\$ = Australian dollar), and gave only similar or lower returns than the bare-rooted plants (A\$0.54 to A\$3.73 vs. A $\$ 1.40$ to A\$4.09). It can be concluded that containerized strawberry plants are not economically viable in subtropical Queensland under the current price structure and growing system. There was a strong relationship between yield and average plant dry weight (leaves, crowns, and roots) in 'Festival' in the last three experiments, where harvesting continued to late September or early October. Productivity increased by about $18 \mathrm{~g}$ for each gram increase in plant dry weight, indicating the dependence of fruit production on vegetative growth in this environment.

S trawberry growers in Australia produce about $50,000 \mathrm{Mg}$ of fruit worth A $\$ 240$ million each year. The industry represents less than $1 \%$ of world production, but it is significant in the context of the local horticultural scene. It has about 500 producers and 18,000 fulland part-time employees (Herrington and Chandler, 2006; Morrison and Herrington, 2002). The main production centers are located in Queensland, Victoria, and Western Australia, with production in Queensland worth A\$140 million.

Producers on the Sunshine Coast in southeastern Queensland grow strawberries over winter in a subtropical environment, and use mainly short-day cultivars supplied each year as bare-rooted plants grown at about

Department of Employment, Economic Development and Innovation, P.O. Box 5083, SCMC, Nambour, Queensland 4560, Australia

We thank Horticulture Australia Limited, Strawberries Australia, the Queensland Strawberry Growers' Association, Sweets Strawberry Runners, Red Jewel Nursery, Dylan Drysdale, and the farm staff at Maroochy Research Station.

${ }^{1}$ Corresponding author. E-mail: chris.menzel@deedi. qld.gov.au.
$900 \mathrm{~m}$ elevation at Stanthorpe in southern Queensland (lat. 28.6 ${ }^{\circ} \mathrm{S}$, long. $152.0^{\circ} \mathrm{E}$ ). Some nursery material is also supplied from Toolangi in Victoria (lat. $37.6^{\circ} \mathrm{S}$, long. $145.5^{\circ} \mathrm{E}$ ). Small numbers of plants have been supplied in containers from the two nurseries in southern Queensland over the past 5 years, although the productivity of this material compared with that of bare-rooted plants is unknown.

Containerized plants are used by some strawberry producers in Europe, the United States, and Mexico (Caracciolo et al., 2009; Dávalos-
González et al., 2009; Durner and Poling, 2000; Durner et al., 2002; Hennion et al., 1993, 1997; Lieten, 2000; Probasco and Garrison, 2003), and on planting out, have undisturbed root systems compared with traditional bare-rooted plants. The poor root system of bare-rooted plants results in plant water deficits, the main reason for the failure of this material during establishment in many locations. This can cause losses in individual fields in southeastern Queensland that range up to $20 \%$ in some seasons.

Containerized plants are easier to plant compared with bare-rooted plants, they establish more readily, have fewer pests and diseases, use less water during establishment, and can be planted mechanically (Bish et al., 1997, 2002; Crawford et al., 2000; Durner and Poling, 2000; Maas, 2000; Poling and Maas, 2000; Poling and Parker, 1990). Containerized plants can also have earlier production, higher yields, and larger fruit than bare-rooted plants (Lieten, 2000; Poling and Maas, 2000).

Most of the research on containerized plants has been conducted in Europe, the northeastern U.S., and Canada, where strawberries traditionally are grown as a summer crop or as a protected crop under plastic tunnels. While there has also been some evaluation of containerized plants in Spain and California, which have Mediterranean climates, there has been limited testing of this material in the subtropics.

Bish et al. (1997) were the first researchers to evaluate the potential of containerized plants in Florida. This area has a subtropical climate, with growers producing berries over winter, similar to producers in southeastern Queensland. Bish and his colleagues found that containerized plants yielded about $375 \mathrm{~g} /$ plant

\begin{tabular}{llll}
\hline $\begin{array}{l}\text { Units } \\
\begin{array}{l}\text { To convert U.S. to SI, } \\
\text { multiply by }\end{array}\end{array}$ & U.S. unit & SI unit & $\begin{array}{l}\text { To convert SI to U.S., } \\
\text { multiply by }\end{array}$ \\
\hline 0.4047 & acre $(\mathrm{s})$ & $\mathrm{ha}$ & 2.4711 \\
0.3048 & $\mathrm{ft}$ & $\mathrm{m}$ & 3.2808 \\
9.3540 & gal/acre & $\mathrm{L} \cdot \mathrm{ha}^{-1}$ & 0.1069 \\
2.54 & inch(es) & $\mathrm{cm}$ & 0.3937 \\
25.4 & inch(es) & $\mathrm{mm}$ & 0.0394 \\
16.3871 & inch & $\mathrm{cm}^{3}$ & 0.0610 \\
28.3495 & $\mathrm{oz}$ & $\mathrm{g}$ & 0.0353 \\
0.9072 & ton $(\mathrm{s})$ & $\mathrm{Mg}$ & 1.1023 \\
2.2417 & ton $/ \mathrm{acre}$ & $\mathrm{Mg} \cdot \mathrm{ha}^{-1}$ & 0.4461 \\
$\left({ }^{\circ} \mathrm{F}-32\right) \div 1.8$ & ${ }^{\circ} \mathrm{F}$ & ${ }^{\circ} \mathrm{C}$ & $\left(1.8 \times{ }^{\circ} \mathrm{C}\right)+32$ \\
& & &
\end{tabular}


compared with about $200 \mathrm{~g} / \mathrm{plant}$ for bare-rooted plants from nurseries in Florida or from the higher latitude of South Deerfield, MA (lat. $42.3^{\circ} \mathrm{N}$, long. $\left.72.4^{\circ} \mathrm{W}\right)$. These experiments were conducted over a single season in Tampa, FL (lat. $27.6^{\circ} \mathrm{N}$, long. $\left.82.4^{\circ} \mathrm{W}\right)$. The containerized plants were grown in glasshouses in Gainesville, FL, initially at day/night temperatures of $35 / 25^{\circ} \mathrm{C}$, and then at $25 / 15$ or $35 / 25{ }^{\circ} \mathrm{C}$ for the 2 weeks before planting. The plants conditioned at low temperatures yielded more than those conditioned at high temperatures.

Later work by Kokalis-Burelle (2003) found that containerized plants of 'Sweet Charlie' and 'Camarosa' from high latitudes in Minnesota had healthier roots and earlier crops than bare-rooted plants (also from Minnesota) over 3 years. However, these differences in initial growth and production were translated into higher yields for the whole season (12.3 vs. $6.3 \mathrm{Mg} \cdot \mathrm{ha}^{-1}$ ) in only one of six cases. In the other comparisons, the containerized plants yielded $-7 \%$ to $+24 \%$ of the yields of the bare-rooted plants, but these differences were not significant.

Gilreath et al. (2006) reported that there were no differences in total yield between containerized and barerooted plants of 'Chandler' obtained from North Carolina and grown in three locations in Florida over 2 years. Hochmuth et al. (2006) conducted a similar experiment with 'Sweet Charlie', and found that there were no differences in productivity between the two plant types when they were grown with microjet or sprinkler irrigation.

This article reports on the productivity of containerized plants of strawberry from Stanthorpe at an elevation of about $900 \mathrm{~m}$ in southern Queensland, and grown at Nambour on the Sunshine Coast. In the first two experiments, 'Festival' and 'Sugarbaby' (years 1 and 2) and 'Rubygem' (only in year 2 ) were propagated as plants in small, $75-\mathrm{cm}^{3}$ cells, or as bare-rooted plants. In year 3, 'Festival' and 'Rubygem' were propagated as plants in large, $125-\mathrm{cm}^{3}$ cells, or as small or large bare-rooted plants. In the final year, plants in large cells and bare-rooted plants of 'Festival' were planted at four different times from late March to early May.

Our experiments differed from the research conducted in Florida where the containerized plants were generally obtained from nurseries at high elevation or from high latitude in North Carolina (Gilreath et al., 2006; Hochmuth et al., 2006) or Minnesota (Kokalis-Burelle, 2003). These areas are up to $10{ }^{\circ} \mathrm{C}$ cooler than Florida in summer. In contrast, it is about $5{ }^{\circ} \mathrm{C}$ cooler during the time of nursery plant development between January and May at Stanthorpe compared with conditions at Nambour. We also examined the relationship between yield and average plant dry weight during the season in 'Festival', the dominant cultivar in southeastern Queensland. This analysis was carried out to determine the link between reproductive and vegetative growth in this environment.

\section{Materials and methods}

A COMPARISON OF BARE-ROOTED AND CONTAINERIZED PLANTS OF 'Festival' and 'Sugarbaby' (eXPT. 1). Bare-rooted and containerized plants of strawberry cultivars Festival and Sugarbaby from Stanthorpe in southern Queensland (lat. 28.6 ${ }^{\circ} \mathrm{S}$, long. $152.0^{\circ} \mathrm{E}$, elevation $872 \mathrm{~m}$ ) were planted at Nambour on the Sunshine Coast (lat. $26.6^{\circ} \mathrm{S}$, long. $152.9^{\circ} \mathrm{E}$, elevation $29 \mathrm{~m}$ ) on 20 Apr. 2004. The strawberries were grown as commercial crops, with standard horticultural practices (Vock, 1997). The new plants were planted in a silty clay loam through plastic, in double row beds $70 \mathrm{~cm}$ wide and $130 \mathrm{~cm}$ apart from the centers. The plants were spaced at $30-\mathrm{cm}$ intervals within the rows, giving a density of 51,000 plants/ha. The containerized plants were grown in small, $75-\mathrm{cm}^{3}$ cells filled with fine bark, with the tips harvested from the field at Stanthorpe in late January. They remained in plastic houses at Stanthorpe until consigned to Nambour.

The dry weights of the leaves, crown, and roots were determined from samples of each cultivar and plant type $(\mathrm{n}=10$ plants per treatment) at planting (Day 1). Similar data were also collected every 2 to 3 weeks from the plants established in the field up until 6 Aug. (Day 108). Fruit were harvested every week for an assessment of yield (wet weight) and fruit fresh weight up until Day 108. For the growth data, the experiment was laid out in a split-split plot design, with cultivars in the main plots, plant types in the subplots, and harvest dates in the split-split plots. There were two replicate blocks and three plants per plot $(\mathrm{n}=$ six plants per treatment). For the yield data, the experiment was laid out in a split plot design, with cultivars in the main plots, plant types in the split plots, and the fruit harvested each week from the same 10 plants in each plot $(\mathrm{n}=20$ plants per treatment).

The growth data (block means) were analyzed by split-split plot analysis of variance (ANOVA; two cultivars $\times$ two plant types $\times$ five harvests ) using Genstat, version 11, from VSN International Software for Bioscience (Hemel Hempstead, UK). Yield and average seasonal fruit fresh weight data were analyzed by split plot ANOVA (two cultivars $x$ two plant types). Average seasonal fruit fresh weight is the long-term average value of fruit fresh weight pooled across all the harvest dates. Mean average seasonal fruit weight is the long-term average value of fruit fresh weight pooled across all the treatments in an experiment and all the harvest dates.

A COMPARISON OF BARE-ROOTED AND CONTAINERIZED PLANTS OF 'Festival', 'RUBYGEM', AND 'SUgARBABY' (EXPT. 2). The approach was similar to Expt. 1, with barerooted plants of 'Festival', 'Rubygem', and 'Sugarbaby' and plants in small, 75- $\mathrm{cm}^{3}$ cells planted on 19 Apr. 2005 (Day 1), and maintained up until 3 Oct. (Day 179). Two plants were harvested from each of four replicate blocks for the growth data $(\mathrm{n}=$ eight plants per treatment), and the fruit harvested each week from the same 10 plants in each block $(n=40$ plants per treatment). Data analysis was as above.

A COMPARISON OF BARE-ROOTED AND CONTAINERIZED PLANTS OF 'Festival' and 'Rubygem' (eXPT. 3). Small and large bare-rooted plants of 'Festival' and 'Rubygem' and plants in large, $125-\mathrm{cm}^{3}$ cells were grown from 11 Apr. (Day 1) until 26 Sept. 2006 (Day 169). The small barerooted plants had crowns from 7 to $11 \mathrm{~mm}$ in diameter, the large barerooted plants had crowns from 10 to $16 \mathrm{~mm}$, and the containerized plants had crowns from 6 to $12 \mathrm{~mm}$. There were four replicate blocks, with two plants harvested from each plot for the growth data $(\mathrm{n}=$ eight plants per treatment), and the fruit harvested each week from the same 20 plants in each plot $(\mathrm{n}=80$ plants per 
treatment). The data were analyzed as in the first experiment.

A COMPARISON OF BARE-ROOTED AND CONTAINERIZED PLANTS OF 'Festival' PLANTED at DIFFERENT TIMES (EXPT. 4). Bare-rooted plants of 'Festival' and plants in large, 125$\mathrm{cm}^{3}$ cells were planted on 27 Mar. (Day 1), 3 Apr., 17 Apr., or 2 May 2007. The experiment concluded on 9 Oct. (Day 197). There were four replicate blocks, with two plants harvested from each plot for the growth data $(\mathrm{n}=$ eight plants per treatment), and the fruit harvested each week from the same 20 plants in each plot $(\mathrm{n}=80$ plants per treatment). The growth data from Day 50 were analyzed by split-split plot ANOVA (four planting dates $x$ two plant types $\times$ eight harvests). Data on yield and average seasonal fruit fresh weight were analyzed by split plot ANOVA (four planting dates $\times$ two plant types).

OTher analyses. The relationships between leaf, crown, and root dry weight, and total plant weight in the planting material were assessed by regression analysis across the four experiments to determine whether the small and large plants had similar allocations of dry matter to the shoots and roots. We also assessed the relationship between yield and average plant dry weight in 'Festival' during the last three seasons. 'Festival' was chosen because it had the greatest number of data points $(\mathrm{n}=13$ compared with $\mathrm{n}=$ two for 'Sugarbaby' and $\mathrm{n}=$ four for 'Rubygem'). Data from 2004 were excluded from the analysis because the experiment was ended in early August compared with late September or early October in the other experiments. The graphics software SigmaPlot (version 11; Systat, Chicago) was used to analyze these data.

The gross returns of the barerooted and containerized plants in the four experiments were compared using similar analyses as those used to compare yields. The yields from each treatment for each month from June to October were multiplied by the average price received for strawberries in the Brisbane Markets in the period from 2003 to 2006 to give the gross returns for each treatment. The average prices for fruit received in June, July, August, September, and October used in this analysis were $\mathrm{A} \$ 2.28, \mathrm{~A} \$ 1.82$, $\mathrm{A} \$ 1.45, \mathrm{~A} \$ 1.13$, and $\mathrm{A} \$ 1.61$ per
250 -g basket, respectively. The returns for the containerized plants were discounted by $\mathrm{A} \$ 0.28$ to take into account their higher cost compared with that of the bare-rooted plants (A $\$ 0.60$ vs. A $\$ 0.32$ ).

\section{Results}

A COMPARISON OF BARE-ROOTED AND CONTAINERIZED PLANTS OF 'Festival' and 'Sugarbaby' (EXPT. 1). The containerized plants were smaller than the bare-rooted plants at planting, with leaf, crown, and root dry weight all lower (Table 1). The difference between the containerized and barerooted plants in the two cultivars was similar (about a 5- to 7 -fold difference in total plant dry weight), thus the data have been pooled. This also occurred in the other experiments. Growth in the strawberries was coordinated, with small and large nursery plants having similar allocations of dry matter to the leaves, crown and roots (Table 1 ). This also occurred in the other experiments (Fig. 1).

The yields of the containerized plants were $40 \%$ lower than those of the bare-rooted plants, whereas the yields of 'Sugarbaby' and 'Festival' were similar (Table 2). Average seasonal fruit fresh weight $($ mean $\pm \mathrm{SE})$ was higher in 'Festival' $(16.1 \pm 0.6 \mathrm{~g})$ than in 'Sugarbaby' $(15.3 \pm 0.8 \mathrm{~g})$ [least significant difference (LSD) $P=0.05$ and 0.6 , respectively]. In contrast, there was no significant $(P>0.05)$ difference between the two plant types, with an average weight of $16.6 \pm 0.5 \mathrm{~g}$ in the bare-rooted plants and $14.7 \pm$ $0.6 \mathrm{~g}$ in the containerized plants across all harvesting times. Thus, the difference in yield between the two plant types was mainly due to the difference in the number of fruit produced.

The average dry weight of the containerized plants was $28 \%$ lower than that of the bare-rooted plants; however, only the difference in root mass between the two groups of plants was significant (Table 3). The response of the two cultivars was similar, thus only pooled data are presented. The two cultivars also had similar mean plant dry weights. The responses of the treatments were consistent over time, thus only mean values across the season are shown. This also occurred in the other experiments.

A COMPARISON OF BARE-ROOTED AND CONTAINERIZED PLANTS OF 'Festival', 'RubYgem', AND 'SUgARBABY' (EXPT. 2). As in the previous experiment, the containerized plants were smaller than the barerooted plants at planting (Table 1). The containerized plants had 15\% lower yields than the bare-rooted plants, with similar productivity in the

Table 1. The effect of plant type (containerized or bare-rooted plants) on plant dry weight at planting in the experiments with strawberries at Nambour, Australia, in 2004, 2005, and 2006.

\begin{tabular}{lcccr}
\hline & \multicolumn{4}{c}{ Plant dry wt $(\mathbf{g})^{\mathrm{z}}$} \\
\cline { 2 - 5 } Plant type & Leaves & Crown & Roots & Tota \\
\hline & & \multicolumn{2}{c}{ Expt. 1} \\
Bare-rooted plant & 2.8 & 0.8 & 1.7 & 5.3 \\
Plant in small cell & 0.5 & 0.3 & 0.2 & 0.8
\end{tabular}

Bare-rooted plant

Plant in small celly

Small bare-rooted plant ${ }^{\mathrm{x}}$

Large bare-rooted plant ${ }^{\mathrm{x}}$

Plant in large cell ${ }^{\mathrm{y}, \mathrm{x}}$

Maximum $\mathrm{SE}^{\mathrm{w}}$

Expt. 2

2.6

0.7
1.1

3.1

0.9

0.8

0.3

Expt. 3 pooled from 'Festival', 'Rubygem', and 'Sugarbaby' in 2005 (Expt. 2); and means of 20 plants pooled from 'Festival' and 'Rubygem' in 2006 (Expt. 3). The differences between the containerized and bare-rooted plants in the different cultivars each year were similar; $\mathrm{lg}=0.0353 \mathrm{oz}$.

${ }^{y}$ Containerized plants were grown in small, $75-\mathrm{cm}^{3}\left(4.58 \mathrm{inch}^{3}\right)$ cells or large, $125-\mathrm{cm}^{3}\left(7.63 \mathrm{inch}^{3}\right) \mathrm{cells}$ ${ }^{x}$ In Expt. 3 in 2006, the small bare-rooted plants had crowns from 7 to $11 \mathrm{~mm}(0.276-0.433$ inch $)$ in diameter, the large bare-rooted plants had crowns from 10 to $16 \mathrm{~mm}(0.394-0.630 \mathrm{inch})$, and the plants grown in large cells had crowns from 6 to $12 \mathrm{~mm}(0.236-0.472$ inch $)$.

${ }^{w}$ Maximum SE from the SES calculated with the means presented in a column. 


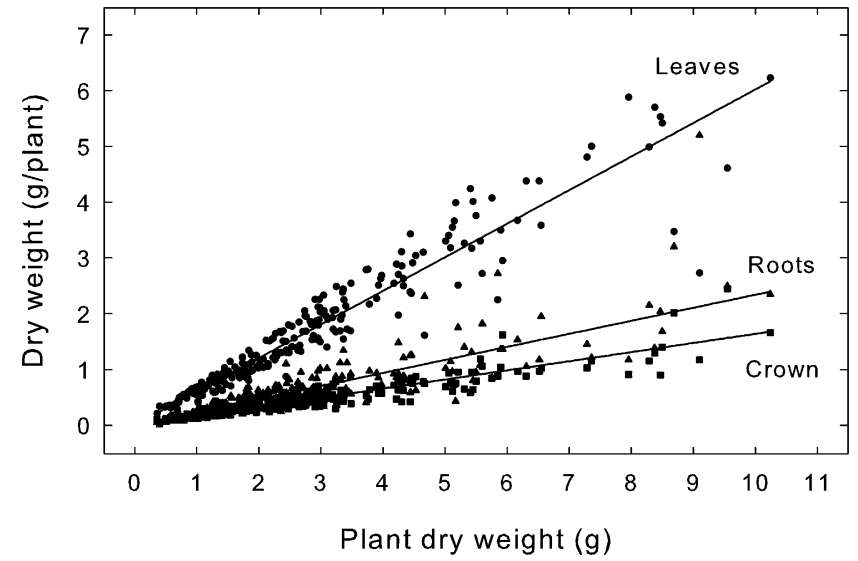

Fig. 1. The relationships between leaf, crown, and root dry weight (DW), and plant DW in containerized and bare-rooted strawberry plants at planting at Nambour, Australia, from 2004 to 2007 . $\mathrm{DW}_{\text {Leaves }}=0.60 \mathrm{DW}_{\text {Plant }}\left(\mathrm{R}^{2}=97 \%\right), \mathrm{DW}_{\text {Crown }}=$ $0.16 \mathrm{DW}_{\text {Plant }}\left(\mathrm{R}^{2}=94 \%\right)$, and $\mathrm{DW}_{\text {Roots }}=0.23 \mathrm{DW}_{\text {Plant }}\left(\mathrm{R}^{2}=86 \%\right)$. Circles = leaves, squares $=$ crown, and triangles $=$ roots; $1 \mathrm{~g}=0.0353 \mathrm{oz}$.

Table 2. The effect of plant type (containerized or bare-rooted plants) and other treatments (cultivar and time of planting) on the yields of the strawberry plants at Nambour, Australia, in 2004, 2005, 2006, and 2007 (Expts. 1-4).

\begin{tabular}{|c|c|c|c|c|}
\hline Year & Plant type & $\begin{array}{c}\text { Yield } \\
(\mathrm{g} / \text { plant })^{\mathrm{z}}\end{array}$ & Other treatments & $\begin{array}{c}\text { Yield } \\
\text { (g/plant) }\end{array}$ \\
\hline \multirow[t]{3}{*}{2004} & Bare-rooted plant & 189 & 'Festival' & 177 \\
\hline & Plant in small celly & 113 & 'Sugarbaby' & 124 \\
\hline & $\operatorname{LSD}(P=0.05)^{\mathrm{x}}$ & 72 & & NS \\
\hline \multirow[t]{4}{*}{2005} & Bare-rooted plant & 703 & 'Festival' & 651 \\
\hline & Plant in small celly & 598 & 'Rubygem’ & 680 \\
\hline & & & 'Sugarbaby' & 619 \\
\hline & $\operatorname{LSD}(P=0.05)$ & 60 & & NS \\
\hline \multirow[t]{4}{*}{2006} & Small bare-rooted plant ${ }^{\mathrm{w}}$ & 470 & 'Festival' & 573 \\
\hline & Large bare-rooted plant ${ }^{\mathrm{w}}$ & 490 & 'Rubygem' & 433 \\
\hline & Plant in large cell ${ }^{\mathrm{y}, \mathrm{w}}$ & 548 & & \\
\hline & $\operatorname{LSD}(P=0.05)$ & NS & & 9 \\
\hline \multirow[t]{5}{*}{2007} & Bare-rooted plant & 686 & Planted on 27 Mar. & 725 \\
\hline & Plant in large cell ${ }^{\mathrm{y}}$ & 670 & Planted on 3 Apr. & 745 \\
\hline & & & Planted on 17 Apr. & 700 \\
\hline & & & Planted on 2 May & 543 \\
\hline & $\operatorname{LSD}(P=0.05)$ & NS & & 72 \\
\hline
\end{tabular}

${ }^{z}$ Data are the mean fresh weights of two to four replicates per treatment. Only the main effect of plant type and other treatments (cultivar or time of planting) are shown. There were no interactions between the two main treatments in each of the experiments; $1 \mathrm{~g}=0.0353 \mathrm{oz}$.

${ }^{y}$ Containerized plants were grown in small, $75-\mathrm{cm}^{3}\left(4.58 \mathrm{inch}^{3}\right)$ cells or in large, $125-\mathrm{cm}^{3}\left(7.63\right.$ inch $\left.{ }^{3}\right)$ cells.

'Least significant difference for the means in an experiment calculated from the analysis of variance; Ns $=$ not significant at $P>0.05$

"In Expt. 3 in 2006, the small bare-rooted plants had crowns from 7 to $11 \mathrm{~mm}(0.276-0.433$ inch $)$ in diameter, the large bare-rooted plants had crowns from 10 to $16 \mathrm{~mm}(0.394-0.630 \mathrm{inch})$, and the plants grown in large cells had crowns from 6 to $12 \mathrm{~mm}(0.236-0.472$ inch).

three cultivars (Table 2). Average seasonal fruit fresh weight was greater in 'Rubygem' (19.1 $\pm 0.5 \mathrm{~g})$ than in 'Festival' (16.8 $\pm 0.4 \mathrm{~g})$ or 'Sugarbaby' $(16.1 \pm 0.4 \mathrm{~g})(\mathrm{LSD} P=0.05$ and 1.0 , respectively). In contrast, average seasonal fruit fresh weight was not significantly $(P>0.05)$ affected by plant type, and was $17.1 \pm 0.3 \mathrm{~g}$ in the bare-rooted plants and $17.6 \pm 0.6 \mathrm{~g}$ in the containerized plants, across all sampling times.

The containerized plants had similar average leaf, crown, and total plant dry weights as the bare-rooted plants, but slightly lower root dry weights (Table 3). The response of the three cultivars was similar, thus only pooled data are presented. Over the season, 'Sugarbaby' plants [27.5 g dry weight
(DW)] were larger than 'Festival' plants (14.5 g DW) or 'Rubygem' plants (17.5 g DW) (LSD $P=0.05$ and 3.7, respectively). The differences in leaf, crown, and root dry weight reflected the differences in total growth amongst the three cultivars (data not presented).

A COMPARISON OF BARE-ROOTED AND CONTAINERIZED PLANTS OF 'Festival' and 'Rubygem' (EXPT. $3)$. The small bare-rooted plants and containerized plants weighed about $35 \%$ of the dry weights of the large bare-rooted plants at planting, with leaf, crown, and root dry weight all lower (Table 1). The containerized plants had similar yields as the small and large bare-rooted plants (Table 2). Yield was greater in 'Festival' than in 'Rubygem'. There was no significant $(P>0.05)$ effect of cultivar or plant type on average seasonal fruit fresh weight, with a general mean across all treatments and harvesting dates of $15.6 \pm 0.4 \mathrm{~g}$.

Average plant dry weight was greatest in the large bare-rooted plants throughout the season (Table 3 ). The response of the two cultivars was similar, thus only pooled data are presented. There were small differences in average plant growth between the two cultivars, with a slightly smaller crown mass in 'Rubygem' $(2.8 \mathrm{~g} /$ plant DW) than in 'Festival' (3.1 g/plant DW) (LSD $P=0.05$ and 0.2 , respectively).

A COMPARISON OF BARE-ROOTED AND CONTAINERIZED PLANTS OF 'Festival' PLANTED AT DIFFERENT TIMES (EXPT. 4). The bare-rooted plants planted on 2 May were larger than those planted earlier (Table 4). The bare-rooted plants were larger than the containerized plants on three occasions (27 Mar., 17 Apr., and 2 May), and were similar to the containerized plants on one occasion (3 Apr.). The material planted on 2 May had about $25 \%$ lower yields than the material planted on 27 Mar., 3 Apr., or 17 Apr. (Table 2). In contrast, there was no significant $(P>0.05)$ effect of plant type on yield. Average seasonal fruit fresh weight was not significantly $(P>$ 0.05 ) affected by plant type or planting date, with a general mean across all treatments and harvesting dates of $14.8 \pm 0.2 \mathrm{~g}$.

Average plant dry weight decreased as planting was delayed, with similar plant dry weights in the barerooted and containerized plants 
Table 3. The effect of plant type (containerized or bare-rooted plant) on average seasonal dry matter production in the strawberries at Nambour, Australia, in 2004, 2005 and 2006 (Expts. 1-3).

\begin{tabular}{|c|c|c|c|c|}
\hline \multirow[b]{2}{*}{ Plant type } & \multicolumn{4}{|c|}{ Plant dry wt $(\mathrm{g})^{\mathrm{z}}$} \\
\hline & Leaves & Crowns & Roots & Total \\
\hline & \multicolumn{4}{|c|}{ Expt. 1} \\
\hline Bare-rooted plant & 10.4 & 3.0 & 1.9 & 15.3 \\
\hline Plant in small cell ${ }^{\mathrm{y}}$ & 8.0 & 2.0 & 1.0 & 11.1 \\
\hline \multirow[t]{2}{*}{$\operatorname{LSD}(P=0.05)^{\mathrm{x}}$} & NS & NS & 0.2 & NS \\
\hline & \multicolumn{4}{|c|}{ Expt. 2} \\
\hline Bare-rooted plant & 13.6 & 4.0 & 3.0 & 20.7 \\
\hline Plant in small cell ${ }^{\mathrm{y}}$ & 12.8 & 3.8 & 2.4 & 19.0 \\
\hline \multirow[t]{2}{*}{$\operatorname{LSD}(P=0.05)$} & NS & NS & 0.4 & NS \\
\hline & \multicolumn{4}{|c|}{ Expt. 3} \\
\hline Small bare-rooted plant ${ }^{w}$ & 10.8 & 2.6 & 1.5 & 14.9 \\
\hline Large bare-rooted plant ${ }^{\mathrm{w}}$ & 12.6 & 3.5 & 2.3 & 18.4 \\
\hline Plant in large cell ${ }^{\mathrm{y}, \mathrm{w}}$ & 9.5 & 2.7 & 1.6 & 13.7 \\
\hline $\operatorname{LSD}(P=0.05)$ & 1.4 & 0.4 & 0.2 & 1.9 \\
\hline
\end{tabular}

${ }^{\mathrm{z}}$ The response of the different cultivars in a given year was similar, thus, only pooled data are presented. Data are the means of four replicates per treatment pooled across 'Festival' and 'Sugarbaby' in 2004 (Expt. 1); means of 12 replicates per treatment pooled across 'Festival', 'Rubygem', and 'Sugarbaby' in 2005 (Expt. 2); and means of eight replicates per treatment pooled across 'Festival' and 'Rubygem' in 2006 (Expt. 3). The responses of the treatments were consistent over time, thus only mean values across the season are shown; $1 \mathrm{~g}=0.0353 \mathrm{oz}$. ${ }^{\mathrm{y}}$ Containerized plants were grown in small, $75-\mathrm{cm}^{3}\left(4.58 \mathrm{inch}^{3}\right)$ cells or large, $125-\mathrm{cm}^{3}\left(7.63 \mathrm{inch}^{3}\right)$ cells. ${ }^{x}$ Least significant difference for the means in an experiment calculated from the analysis of variance; NS $=$ not significant at $P>0.05$.

"In Expt. 3 in 2006, the small bare-rooted plants had crowns from 7 to $11 \mathrm{~mm}(0.276-0.433$ inch) in diameter, the large bare-rooted plants had crowns from 10 to $16 \mathrm{~mm}(0.394-0.630 \mathrm{inch})$, and the plants grown in large cells had crowns from 6 to $12 \mathrm{~mm}(0.236-0.472 \mathrm{inch})$.

Table 4. The effect of plant type (containerized and bare-rooted plants) and planting date on plant dry weight at planting in the experiments with strawberries at Nambour, Australia, in 2007 (Expt. 4).

\begin{tabular}{|c|c|c|c|c|}
\hline \multirow[b]{2}{*}{ Plant type } & \multicolumn{4}{|c|}{ Plant dry wt $(g)^{z}$} \\
\hline & Leaves & Crown & Roots & Total \\
\hline & \multicolumn{4}{|c|}{ Planted on 27 Mar. } \\
\hline Bare-rooted plant & 2.3 & 0.4 & 0.4 & 3.1 \\
\hline \multirow[t]{2}{*}{ Plant in large celly } & 1.0 & 0.3 & 0.3 & 1.6 \\
\hline & \multicolumn{4}{|c|}{ Planted on 3 Apr. } \\
\hline Bare-rooted plant & 2.0 & 0.4 & 0.4 & 2.8 \\
\hline \multirow[t]{2}{*}{ Plant in large celly } & 1.4 & 0.5 & 0.8 & 2.6 \\
\hline & \multicolumn{4}{|c|}{ Planted on 17 Apr. } \\
\hline Bare-rooted plant & 1.9 & 0.5 & 0.6 & 2.9 \\
\hline \multirow[t]{2}{*}{ Plant in large celly } & 1.0 & 0.4 & 0.7 & 2.0 \\
\hline & \multicolumn{4}{|c|}{ Planted on 2 May } \\
\hline Bare-rooted plant & 2.7 & 0.7 & 0.8 & 4.2 \\
\hline Plant in large celly & 1.3 & 0.5 & 0.7 & 2.5 \\
\hline Maximum $\mathrm{SE}^{\mathrm{x}}$ & 0.2 & 0.1 & 0.1 & 0.2 \\
\hline
\end{tabular}

${ }^{\mathrm{z}}$ Data are the means of 10 plants per treatment; $1 \mathrm{~g}=0.0353 \mathrm{oz}$.

${ }^{y}$ Containerized plants were grown in large, $125-\mathrm{cm}^{3}\left(7.63\right.$ inch $\left.^{3}\right)$ cells.

${ }^{x}$ Maximum SE from the SEs calculated with the means presented in a column.

(Table 5 ). The response of the different planting times was similar, thus only pooled data are presented. In addition, the responses of the treatments were consistent over time, thus only mean values across the season are shown.

OTher ANAlyses. There was a strong relationship between yield and average plant dry weight in 'Festival' in the last three experiments, where harvesting continued to late September or early October (Fig. 2). Productivity increased by about $18 \mathrm{~g}$ for each gram increase in plant dry weight, indicating the dependence of yield on leaf, crown, and root growth.

In 2004 and 2005, the plants in small cells were less profitable than the bare-rooted plants, due to their lower yields and their higher cost (Table 6). In 2006, the plants in large cells and bare-rooted plants (small and large) had similar returns. In 2007, the containerized plants had lower returns than the bare-rooted plants, with similar yields being off-set by the higher nursery cost. Overall, the containerized plants gave similar or lower returns than the bare-rooted plants. This analysis did not take into account the lower planting costs associated with containerized plants (300 vs. 150 plants/h) nor their lower water use during establishment.

\section{Discussion}

Strawberries are grown in a subtropical environment in southeastern Queensland, with the nursery material planted in March and April, and the bushes fruiting from May to October. Strawberries are also grown in Florida in a subtropical climate, with the stock planted from September to November (Peres et al., 2006). Most of the material used in Florida is supplied as bare-rooted plants from nurseries above an elevation of 900 $\mathrm{m}$ or from latitudes higher than $42^{\circ} \mathrm{N}$ (Duval et al., 2005). Few containerized plants are used in the industries in southeastern Queensland and Florida.

THE RELATIVE PRODUCTIVITY OF CONTAINERIZED AND BARE-ROOTED PLANTS. The productivity of the containerized plants was evaluated over 11 experiments. There were five sets comparing plants in small cells with bare-rooted plants, and six sets comparing plants in large cells with barerooted plants. The plants in small cells had lower yields than the bare-rooted plants, and the plants in large cells had similar yields as the bare-rooted plants.

Most of the research on containerized plants has been conducted in the temperate-growing areas of Europe, the northeastern U.S., and Canada. In these environments, the berries are mainly grown as a summer crop or as 
Table 5. The effect of time of planting on average seasonal dry matter production in 'Festival' strawberries (containerized and bare-rooted plants) at Nambour, Australia, in 2007 (Expt. 4).

\begin{tabular}{lcccr}
\hline & \multicolumn{4}{c}{${\text { Plant dry wt }(\mathbf{g})^{\mathrm{z}}}$} \\
\cline { 2 - 5 } Time of planting & Leaves & Crowns & Roots & Total \\
\hline 27 Mar. & 14.3 & 5.6 & 3.6 & 23.5 \\
3 Apr. & 14.0 & 5.4 & 3.2 & 22.5 \\
17 Apr. & 10.9 & 3.8 & 2.6 & 17.4 \\
2 May & 8.6 & 3.0 & 2.4 & 14.0 \\
LSD $(P=0.05)^{\mathrm{y}}$ & 0.9 & 0.4 & 0.5 & 1.4 \\
\hline
\end{tabular}

${ }^{\mathrm{z}}$ Data are the means of eight replicates per treatment pooled across the bare-rooted plants and plants grown in large, $125-\mathrm{cm}^{3}\left(7.63 \mathrm{inch}^{3}\right)$ cells. The bare-rooted and containerized plants had similar plant dry weights. The responses of the treatments were consistent over time, thus only mean values across the season are shown; $1 \mathrm{~g}=$ $0.0353 \mathrm{oz}$.

yeast significant difference for the means in an experiment calculated from the analysis of variance.

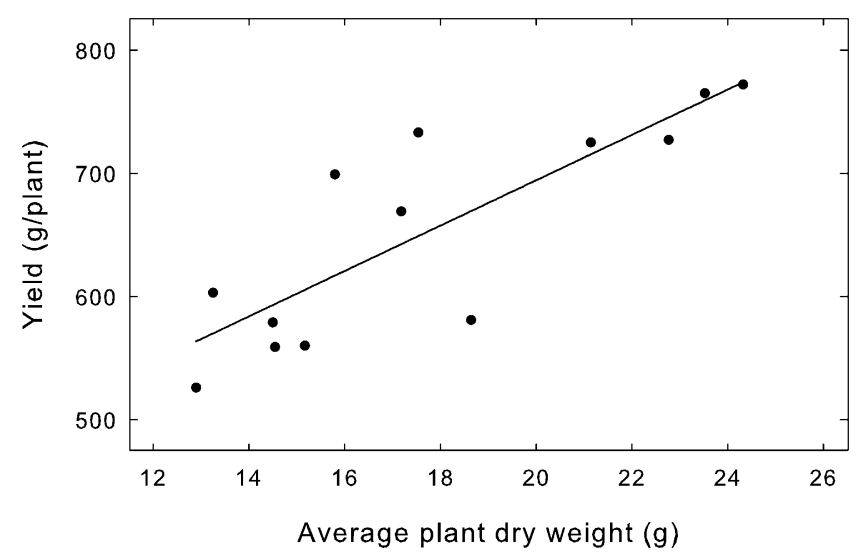

Fig. 2. The relationship between yield and average plant dry weight [DW (leaves, crowns, and roots)] during the season in containerized and bare-rooted 'Festival' strawberry plants at Nambour, Australia, from 2005 to 2007. Data are the means of four replicates per treatment. Yield $=326.1+18.4 \mathrm{DW}_{\text {Plant }}\left(\mathrm{R}^{2}=99 \%\right)$; $1 \mathrm{~g}=0.0353 \mathrm{oz}$.

Table 6. The effect of plant type (containerized or bare-rooted plant) on gross returns in Australian dollars (A\$) of the strawberries in the experiments at Nambour, Australia, from 2004 to 2007 (Expts. 1-4).

\begin{tabular}{|c|c|c|c|}
\hline \multirow[b]{2}{*}{ Year } & \multicolumn{2}{|c|}{ Return (A\$/plant $)^{\mathrm{z}}$} & \multirow[b]{2}{*}{$\operatorname{LSD}(P=0.05)^{\mathrm{y}}$} \\
\hline & & Plant type & \\
\hline 2004 & $\begin{array}{c}\text { Plant in small cell } \\
0.54\end{array}$ & $\begin{array}{c}\text { Bare-rooted plant } \\
1.40\end{array}$ & 0.70 \\
\hline
\end{tabular}

2005 Plant in small cell Bare-rooted plant $3.07 \quad 3.95$

2006 Plant in large cell ${ }^{\mathrm{x}, \mathrm{w}} \quad$ Small bare-rooted Large bare-rooted plant $^{\mathrm{w}}$

$$
2.85
$$

2.61

2.79

NS

2007 Plant in large cell Bare-rooted plant

$$
3.73
$$
4.09

${ }^{2}$ Data are the means of 4 to 12 replicates per treatment, pooled across the different cultivars $(2004,2005$, and 2006 ) and the different planting times (2007). The values for the containerized plants have been discounted to take into account their higher cost compared with that of bare-rooted plants (A\$0.60 vs. A\$0.32); A\$1.00 = US\$0.9270.

yeast significant difference for the means in an experiment calculated from the analysis of variance; Ns = not significant at $P>0.05$

${ }^{x}$ Containerized plants were grown in small, $75-\mathrm{cm}^{3}\left(4.58 \mathrm{inch}^{3}\right)$ cells or large, $125-\mathrm{cm}^{3}\left(7.63 \mathrm{inch}^{3}\right)$ cells

"In Expt. 3 in 2006, the small bare-rooted plants had crowns from 7 to $11 \mathrm{~mm}(0.276-0.433$ inch $)$ in diameter, the large bare-rooted plants had crowns from 10 to $16 \mathrm{~mm}(0.394-0.630 \mathrm{inch})$, and the plants grown in large cells had crowns from 6 to $12 \mathrm{~mm}(0.236-0.472 \mathrm{inch})$. a protected crop under plastic in winter. In one of the earliest experiments in France, Hennion et al. (1993) found that slightly more of the containerized plants established ( $97 \%$ of the containerized plants vs. $87 \%$ of the bare-rooted plants). In contrast, the two groups of strawberries had similar yields on a per plant basis. In a later study in Portugal, containerized plants had similar yields to bare-rooted plants in the first year (1092 vs. $1069 \mathrm{~g} / \mathrm{plant}$ ) and higher yields in the second year (1085 vs. 776 $\mathrm{g} /$ plant) (Palha et al., 2002). In a similar experiment in the same area using plastic tunnels, containerized plants had higher yields than bare-rooted plants over a single season (Palha et al., 2009). D'Anna et al. (2003) found that containerized plants of four cultivars grown under plastic in Italy cropped $62 \mathrm{~d}$ earlier than bare-rooted plants, although average yields were similar for the two groups of stock.

In the United States and Canada, most of the interest in containerized plants has come from producers along the Atlantic coast. Lareau and Lamarre (1993) examined the performance of planting systems on the productivity of 'Kent' and 'Glooscap' at two sites near Montreal, Canada. When the containerized plants were planted in early July, they had higher yields for each $4 \mathrm{~m}$ of row than dormant barerooted plants dug in Spring in 1 year ( 8.5 vs. $6.0 \mathrm{~kg})$, and lower yields in another ( 8.0 vs. $13.8 \mathrm{~kg})$. Fiola and Lengyen (1996) investigated the potential of containerized plants for early plantings further south in New Jersey, and showed that they had higher yields than dormant bare-rooted plants in all four cases investigated ('Chandler' and 'Allstar' planted in early August and in early September). The containerized plants yielded almost twice as much as the bare-rooted plants (10.8 vs. $5.6 \mathrm{Mg} \cdot \mathrm{ha}^{-1}$ ).

Nearly all of the one billion strawberry plants produced in California are supplied as bare-rooted plants from nurseries at high elevation (Strand, 2008). Larson et al. (2002) showed that containerized plants propagated at high elevation $(1200 \mathrm{~m})$ and high latitude $\left(42^{\circ} \mathrm{N}\right)$ produced greater early and total yields than bare-rooted plants, with similar fruit quality. Containerized plants propagated at low elevation $(50 \mathrm{~m})$ and then transported to a high elevation and high latitude site for 3 to 4 weeks of conditioning 
also produced greater and earlier yields than bare-rooted plants. However, this material produced a significant proportion of fruit smaller than $20 \mathrm{~g}$.

No commercial strawberry nursery in California has ever produced containerized plants for sale. In Florida, the use of containerized plants has declined dramatically during the past 5 years. The containerized plants used in these regions are two to four times more expensive than bare-rooted plants. Transportation costs for containerized plants are also up to 10 -fold greater and producers need to recycle or return the expensive plant trays. These costs must be weighed against the potential savings in irrigation (a potential issue in the future in Florida) and possible higher prices for early fruit. An economic analysis of the returns of the different planting material used in the current experiments showed that containerized plants had similar or lower returns than barerooted plants. There were no cases where the containerized plants were more profitable. This analysis took into account the difference in the cost of the nursery material, with the containerized plants costing A $\$ 0.60$ and the bare-rooted plants costing A $\$ 0.32$. These results suggest that containerized plants are not economically viable in subtropical Queensland under the current price structure and growing system.

Containerized plants could become profitable in the future if the potential savings in planting and watering at establishment are taken into account, and the cost of the nursery material decreases. Bare-rooted plants require several hours of overhead irrigation each day for the first 2 weeks after planting to establish. Reducing plant establishment water use by $80 \%$ would save $30 \%$ of total crop water use on the Sunshine Coast, or 1.8 million liters for each hectare of strawberries.

Duval et al. (2005) investigated the economics of bare-rooted and containerized plants in Florida. The yields of the plants were multiplied by the average price received for fruit during the two seasons of the experiment. No attempt was made to include factors such as water and transplant costs into the analysis. Bare-rooted plants returned US\$6179 more for each acre of berries than containerized plants. These authors noted that bare-rooted plants cost US $\$ 0.075$ to US\$0.125 in
Florida compared with US\$0.175 to US\$0.250 for containerized plants.

The nursery material for the current experiments was obtained from Stanthorpe, at an elevation of about $900 \mathrm{~m}$ in southern Queensland, whereas the plants were subsequently grown on the Sunshine Coast. In Florida, the bulk of the nursery material originates from out-of-state, with the new plants grown in the northern U.S. or Canada (Duval et al., 2005). Research conducted in the late 1990s showed that bare-rooted plants from Stanthorpe had higher yields over a single season than bare-rooted plants from the coast (C.M. Menzel, unpublished data). More recent research showed that bare-rooted plants from southern Australia (cool-growing areas) had similar yields over three seasons as bare-rooted plants from Stanthorpe (a warm-growing area) (C.M. Menzel, unpublished data). The southern areas are about 3 to $5{ }^{\circ} \mathrm{C}$ cooler during the growth of the nursery plants compared with conditions at Stanthorpe. It was concluded from these studies that material from Stanthorpe was just as productive as material from Victoria or Tasmania.

The Relationship Between PRODUCTIVITY AND PLANT GROWTH. Fruit production in strawberry is dependent on the initiation of successive inflorescences and on the vegetative development of the plant (Darnell, 2003). In our experiments, the plants in small cells had lower yields than the plants in large cells or the bare-rooted plants. The average dry weight of the plants in small cells at planting was $1.1 \mathrm{~g}$ compared with $2.0 \mathrm{~g}$ for the plants in large cells and $3.6 \mathrm{~g}$ for the bare-rooted plants. These results suggest that small differences in the size of the nursery material can translate into large differences in fruit production in subtropical Queensland.

Bish et al. (2002) found that plants in $300-\mathrm{cm}^{3}$ cells had higher root dry weights than those in $75-\mathrm{cm}^{3}$ cells in 2 of 2 years in Florida, and higher leaf dry weights in 1 of 2 years. However, these differences in initial plant growth did not necessarily translate into greater fruit production, as plants in the large containers yielded $31 \%$ more than those in the small containers in year 1 , and $22 \%$ less in year 2 . It can be concluded from these studies that the effect of container size varies from season to season in Florida.
In contrast, plants in large cells performed better than plants in small cells in southeastern Queensland.

'Festival' is the dominant cultivar in southeastern Queensland, and accounts for about $70 \%$ of production. We examined the relationship between yield and average plant dry weight in this cultivar in the last three experiments where harvesting continued up to at least late September. There was a strong relationship between yield and plant dry weight, with productivity increasing by about $18 \mathrm{~g}$ for each gram increase in dry weight. Generally, nursery material smaller than $2 \mathrm{~g}$ or material planted in early May produced the smaller plants and the lower yields. These data confirm the importance of new leaf, crown, and root growth for fruit production.

AVERAGe FRUIT FRESH WEIGHT. The containerized and bare-rooted plants produced similar-sized fruit on the Sunshine Coast over 4 years, in agreement with the results reported in Florida. For instance, Hochmuth et al. (2006) found that average fruit fresh weight ranged from 14.3 to $15.9 \mathrm{~g}$ in bare-rooted and containerized plants under sprinkler irrigation over 2 years at Dover. In contrast, the experience in California is that containerized plants sometimes produced small fruit (Larson et al., 2002). Research conducted in Europe (D'Anna et al., 2003; Palha et al., 2002) and in the northeastern U.S. and Canada (Fiola and Lengyen, 1996; Lareau and Lamarre, 1993) found small or inconsistent differences in average berry weight between the two different plant types.

Strawberry plants grown in $75-\mathrm{cm}^{3}$ cells produced $60 \%$ to $85 \%$ of the yields of bare-rooted plants, whereas plants in $125-\mathrm{cm}^{3}$ cells produced close to $100 \%$ of the yields of the bare-rooted plants. Containerized plants are twice as expensive as bare-rooted plants (A $\$ 0.60$ vs. A $\$ 0.32$ ), and gave similar or lower returns than the bare-rooted plants. These results suggest that containerized plants are not economically viable in subtropical Queensland with the current price structure and growing system.

\section{Literature cited}

Bish, E.B., D.J. Cantliffe, and C.K. Chandler. 2002. Temperature conditioning 
and container size affect early season fruit yield of strawberry plug plants in a winter, annual hill production system. HortScience 37:762-764.

Bish, E.B., D.J. Cantliffe, G.J. Hochmuth, and C.K. Chandler. 1997. Development of containerized strawberry transplants for Florida's winter production system. Acta Hort. 439:461-468.

Caracciolo, G., A. Moncada, C. Prinzivalli, and F. D'Anna. 2009. Effects of planting dates on strawberry plug performance in Sicily. Acta Hort. 842:155-158.

Crawford, T.D., D.G. Himelrick, J.L. Sibley, and J.A. Pitts. 2000. Effect of runner plantlet size on performance of strawberry plug plants. Small Fruits Rev. $1: 15-21$.

D'Anna, F., C. Prinzivalli, W. Faedi, and G. Baruzzi. 2003. Performance of cold stored and plug strawberry plants grown under tunnel. Acta Hort. 614:131-134.

Darnell, R.L. 2003. Strawberry growth and development, p. 3-10. In: N.F. Childers (ed.). The strawberry: A book for growers, others. Dr. Norman F. Childers Publications, Gainesville, FL.

Dávalos-González, P.A., J. Narro-Sánchez, A.E. Jofre-Garfias, A.R. Hernández Razo, and M.N. Vázquez-Sánchez. 2009. Influence of the genotype, type of plant and population density on strawberry productivity and fruit quality under macrotunnel. Acta Hort. 842:91-94.

Durner, E.F. and E.B. Poling. 2000. Phytotron research investigations with conditioned 'Sweet Charlie' and 'Camarosa’ plugs. Acta Hort. 513:403-408.

Durner, E.F., E.B. Poling, and J.L. Maas. 2002. Recent advances in strawberry plug transplant technology. Hort Techology 12:545-550.

Duval, J.R., C.K. Chandler, and E. Golden. 2005. Planting date affects early season fruit yield of strawberry in a subtropical environment. J. Amer. Pomol. Soc. 59:7-12.
Fiola, J.A. and R. Lengyen. 1996. Plug transplants are superior to dormant transplants for productivity in strawberry plasticulture. Proc. Fourth North Amer. Strawberry Conf., Orlando, FL. p. 288291.

Gilreath, J.P., B.M. Santos, J.W. Noling, S.J. Locascio, D.W. Dickson, E.N. Rosskopt, and S.M. Olson. 2006. Performance of containerized and bare-root transplants with soil fumigants for Florida strawberry production. HortTechology 16:461-465.

Hennion, B., A. Bardet, and J. Longuesserre. 1993. Performance of plug strawberry plants established from unrooted runners. Acta Hort. 348:237-239.

Hennion, B., J. Schupp, and J. Longuesserre. 1997. "Fraisimotte ${ }^{\circledR} "$ : A strawberry plug plant developed by CIREF in France. Acta Hort. 439:469-474.

Herrington, M.E. and C.K. Chandler. 2006. Strawberry breeding in a subtropical environment. Acta Hort. 708:441447.

Hochmuth, G., D. Cantliffe, C. Chandler, C. Stanley, E. Bish, E. Waldos, D. Legard, and J. Duval. 2006. Fruiting responses and economics of containerized and bare-root strawberry transplants established with different irrigation methods. Hort Techology 16:205-210.

Kokalis-Burelle, N. 2003. Effects of transplant type, plant growth-promoting rhizobacteria, and soil treatment on growth and yield of strawberry in Florida. Plant Soil 256:273-280.

Lareau, M.J. and M. Lamarre. 1993. Late planting of strawberries using bare root or plug plants. Acta Hort. 348:245-248.

Larson, K.D., E.E. Ponce, and D.V. Shaw. 2002. Containerized strawberry transplants as a replacement for methyl bromide soil fumigation in California strawberry nurseries. University of California, Davis.
Lieten, F. 2000. Recent advances in strawberry plug transplant technology. Acta Hort. 513:383-388.

Maas, J.L. 2000. Opportunities to reduce the potential for disease infection and spread with strawberry plug plants. Acta Hort. 513:409-414.

Morrison, B. and M. Herrington. 2002. Strawberry breeding in Australia. Acta Hort. 567:125-128.

Palha, M.G., J.L. Campo, T. Curado, M.B. Sousa, and P.B. Oliveira. 2009. 'Elsanta' autumn crop performance using different plant types and planting dates. Acta Hort. 842:983-986.

Palha, M.G.S., M.C.S. Andrade, and M.J.P. Silva. 2002. The effects of different types of plant production on strawberry yield and fruit quality. Acta Hort. 567:515-518.

Peres, N.A., J.F. Price, W.M. Stall, C.K. Chandler, S.M. Olson, T.G. Taylor, S.A. Smith, and E.H. Simonne. 2006. Strawberry production in Florida, p. 375-382. In: S.M. Olson (ed.). The vegetable production guide for Florida. Florida Coop. Ext. Serv., Inst. Food Agr. Sci., Univ. of Florida, Gainesville.

Poling, E.B. and J.L. Maas. 2000. Strawberry plug transplant technology. Acta Hort. 513:393-401.

Poling, E.B. and K. Parker. 1990. Plug production of strawberry transplants. Adv. Strawberry Production 9:37-39.

Probasco, P.R. and S.A. Garrison. 2003. Comparison of strawberry plugs from dormant plants to Canadian tip cuttings. Acta Hort. 626:231-233.

Strand, L.L. 2008. Integrated pest management for strawberries. Univ. California Agr. and Natural Resources Publ. No. 3351 .

Vock, N. 1997. Strawberry information kit. Dept. Primary Industries, Nambour, Queensland, Australia. (no page numbers). 